\title{
Characterization of dissolved organic matter (DOM) from glacial environments using total fluorescence spectroscopy and parallel factor analysis
}

\author{
Ashley DUBNICK, ${ }^{1}$ Joel BARKER, ${ }^{2}$ Martin SHARP, ${ }^{1}$ Jemma WADHAM, ${ }^{3}$ Grzegorz LIS, ${ }^{3}$ \\ Jon TELLING, ${ }^{3}$ Sean FITZSIMONS, ${ }^{4}$ Miriam JACKSON ${ }^{5}$
}

${ }^{1}$ Department of Earth and Atmospheric Sciences, University of Alberta, 1-26 Earth Sciences Building, Edmonton,
Alberta T6G 2E3, Canada
E-mail: adubnick@ualberta.ca
${ }^{2}$ School of Earth Sciences, Ohio State University, 125 South Oval Mall, Columbus, OH 43210-1308, USA
${ }^{3}$ School of Geographical Sciences, University of Bristol, University Road, Bristol BS8 1SS, UK
${ }^{4}$ Department of Geography, University of Otago, PO Box 56, Dunedin, New Zealand
${ }^{5}$ Norwegian Water Resources and Energy Directorate (NVE), PO Box 5091, Majorstua, NO-0131 Oslo, Norway

\begin{abstract}
Aquatic dissolved organic matter (DOM) is a major reservoir of reduced organic carbon and has a significant influence on heterotrophic biological productivity and water quality in marine and freshwater environments. Although the forms and transformations of DOM in temperate aquatic and soil environments have been studied extensively, this is not the case for glacial environments. In this study, fluorescent excitation-emission matrices (EEMs), parallel factor analysis (PARAFAC) and cluster analysis were used to characterize the fluorescing components of DOM in ice and water samples from supraglacial, englacial, subglacial and proglacial environments of seven glaciers in the Canadian Arctic, Norway and Antarctica. At least five significant fluorescent DOM fractions were identified, which accounted for $98.2 \%$ of the variance in the dataset. These included four protein-like components and one humic-like component. The predominantly proteinaceous character of DOM from these glaciers is very different from the more humic character of DOM described previously from lacustrine, fluvial, estuarine and marine environments. DOM from the sampled glaciers is broadly similar in character despite their geographically distinct locations, different thermal regimes and inter- and intra-site differences in potential organic matter sources. Glacier ice samples had a relatively low ratio of humiclike: protein-like fluorescence while meltwater samples had a higher ratio.
\end{abstract}

\section{INTRODUCTION}

The presence and properties of organic matter (OM) influence nutrient availability, metal solubilization and carbon biogeochemistry in aquatic ecosystems (Findlay and Sinsabaugh, 2003; Mulholland, 2003; Banaitis and others, 2006). The distinction has been made between two important forms of OM: particulate organic matter (POM) and dissolved organic matter (DOM). DOM is defined operationally as OM that passes through filters $0.2-0.8 \mu \mathrm{m}$ in size (Coble, 2007). DOM typically comprises the largest OM fraction in aquatic systems and is generally considered to be more ecologically significant than POM (Findlay and Sinsabaugh, 2003).

The characteristics and ecological functions of DOM in temperate aquatic environments have been studied extensively (e.g. Coble, 1996; Stedmon and others, 2003; Holbrook and others, 2006; Yamashita and others, 2008). However, the role of DOM in glacial environments remains largely unknown, despite evidence that glaciers export DOM and a significant component of this DOM is potentially labile (Lafrenière and Sharp, 2004; Barker and others, 2006, 2009; Hood and others, 2009). As glacier melt rates increase in response to climate warming, so too will the export of glacially derived DOM, and the effects of this DOM on downstream environments may become increasingly important ecologically. Therefore, there is a need to understand the forms and transformations of DOM in glacier systems as these will exert a first-order effect on DOM function in downstream ecosystems.

\section{Organic matter and glacier systems}

Glaciers incorporate OM from both allochthonous and autochthonous sources. As glaciers advance over OM in proglacial vegetation and soils (Wadham and others, 2008; Barker and others, 2009), allochthonous OM can be incorporated into basal ice and/or sequestered in the subglacial environment. Allochthonous OM may also be supplied by precipitation, supraglacial streamflow or aeolian transport. Supraglacially deposited OM can be incorporated into glacier ice during the firnification of snow or by transport along englacial hydrological pathways. OM may be incorporated into basal ice from freezing of subglacial meltwaters that are produced by melting at the glacier bed, from waters that are routed from the glacier surface, or through the incorporation of extraglacial sediments and waters during basal ice formation. Autochthonous $\mathrm{OM}$ is produced by heterotrophic and/or autotrophic microbial activity. Viable microbial communities have been found in subglacial (e.g. Sharp and others, 1999; Skidmore and others, 2000, 2005; Foght and others, 2004; Bhatia and others, 2006), englacial (Price, 2000; Priscu and others, 2006) and supraglacial (e.g. Bhatia and others, 2006; Stibal and others, 2006) environments. Evidence indicating that glacial microbial communities are active (Wadham and others, 2004; Skidmore and others, 2005) suggests that they may play an important role in DOM cycling through the production and consumption of DOM in glacial systems. 


\section{Characterizing DOM using spectrofluorescence}

Glacier ice and meltwaters contain relatively low concentrations of DOM, typically less than 2 ppm as organic carbon (Lafrenière and Sharp, 2004; Barker and others, 2006; Bhatia and others, 2006). Thus, large sample volumes are required to isolate sufficient $\mathrm{OM}$ for detailed compositional characterization using techniques such as ${ }^{13} \mathrm{C}$ or ${ }^{1} \mathrm{H}$ nuclear magnetic resonance (NMR) spectroscopy, high-performance liquid chromatography (HPLC) and electrospray ionization Fourier transform ion cyclotron resonance mass spectrometry (ESI-FTICR-MS) (e.g. Leenheer and Croué, 2003; Sleighter and Hatcher, 2008; Bhatia and others, 2010). Total fluorescence spectroscopy is a sensitive technique that requires small sample volume and DOM concentration and little sample preparation, making it well suited to characterizing the fluorescing components of DOM in dilute solutions from a large number of samples.

Several DOM fractions are composed of fluorophores, compounds that absorb and re-emit electromagnetic energy (Mopper and others, 1996). Studies of DOM fluorescence have shown that specific fluorophores are associated with the presence of particular compounds in the DOM (e.g. Coble, 1996, 2007; Coble and others, 1998; Lakowicz, 1999; Marhaba and Lippincott, 2000; Marhaba and others, 2000; Parlanti and others, 2000). These fluorescent signatures do not directly identify the presence of specific compounds, but they do provide evidence for the presence of DOM fractions that can be characterized as, for example, humic-like, fulvic-like, tryptophan-like or tyrosine-like (Hudson and others, 2007). Here, mixtures of tryptophanand/or tyrosine-like DOM are referred to as proteinaceous.

The total spectrofluorescence of DOM in a sample is represented by an excitation-emission matrix (EEM). EEMs comprise a series of fluorescence scans that measure light emitted over a range of wavelengths as the result of excitation at series known wavelengths, yielding a 'map' of fluorophore intensity (Coble and others, 1990). Fluorophores in DOM can be identified by the location and shape of their peak fluorescence intensity in the EEM and can be compared between samples. Total spectrofluorescence has the advantage of describing fluorescence over a broad range of wavelengths and is thus more suitable than other spectrofluorescent techniques for analyzing DOM that contains multiple fluorophores.

\section{Parallel factor analysis (PARAFAC)}

EEMs have often been interpreted visually by noting the emission and excitation coordinates of fluorophore peak intensities (e.g. Coble, 1996). For example, tyrosine-like fluorescence has a peak at wavelengths of $275 \mathrm{~nm}$ excitation and $310 \mathrm{~nm}$ emission (Coble, 1996). However, fluorophores cannot always be distinguished satisfactorily using visual analysis as individual peaks may overlap or be poorly resolved (Bro, 1997). Owing to the inherent complexity of spectral signatures arising from a complex mixture of DOM fractions in natural waters, parallel factor analysis (PARAFAC) provides a less subjective way to interpret a complex EEM (Stedmon and others, 2003). PARAFAC reduces the dimensions of a dataset and allows for the identification of a small number of prominent fluorophores.

PARAFAC is designed for the analysis of data arrays with more than two dimensions (Rutledge and Bouveresse, 2007). When applied to EEMs, PARAFAC decomposes threedimensional spectral signatures that may involve multiple overlapping fluorophores into loadings associated with individual components that can be related to specific DOM fractions (Bro, 1997; Andersen and Bro 2003; Smilde and others, 2004). PARAFAC yields a model that represents a unique solution obtained by a least-squares fit to observations that minimizes residuals (Bro, 1999; Ohno and Bro, 2006). This model may then be applied to the interpretation of the original array of EEMs. Andersen and Bro (2003) provide comprehensive descriptions of the development of PARAFAC.

\section{METHODS \\ Field sites}

Eighty ice and meltwater samples were analyzed for their fluorescence properties. Samples were obtained from: Clark Glacier (CG), Suess Glacier (SG), Victoria Upper Glacier (VUG) and Lower Wright Glacier (LWG), McMurdo Dry Valleys, Antarctica; John Evans Glacier (JEG) and Prince of Wales Icefield (PoW), Ellesmere Island, Canada; and Engabreen (EG) in the Norwegian Arctic (Table 1).

The Antarctic glaciers are cold throughout (cold-based polar glaciers), with ice temperatures below the pressuremelting point. Proglacial lakes, which may be a source of lacustrine OM, are found in front of SG, VUG and LWG. There were several large proglacial lakes in the McMurdo Dry Valleys during the Last Glacial Maximum (LGM) and early Holocene (Hall and others, 2001). Any of the glaciers sampled may have advanced over lacustrine sediments and incorporated associated OM into their basal ice layers, either as POM in sediment or DOM in basal ice formed by freezing of lake water and/or sediment pore water to the glacier sole (Souchez and Jouzel, 1984). CG contains a considerable amount of englacial and surficial wind-blown dust, suggesting a possible aeolian OM input derived from exposed proglacial lake sediments, embryonic soils and/or

Table 1. Glacier systems and samples

\begin{tabular}{|c|c|c|c|}
\hline Glacier system & Location & Latitude, Longitude & Date sampled \\
\hline Clark (CG) & McMurdo Dry Valleys, Antarctica & $75^{\circ} 34^{\prime} \mathrm{S}, 162^{\circ} 05^{\prime} \mathrm{E}$ & Nov/Dec 2004 \\
\hline Suess (SG) & McMurdo Dry Valleys, Antarctica & $77^{\circ} 38^{\prime} \mathrm{S}, 162^{\circ} 40^{\prime} \mathrm{E}$ & Nov/Dec 2004 \\
\hline Upper Victoria (VUG) & McMurdo Dry Valleys, Antarctica & $77^{\circ} 16^{\prime} \mathrm{S}, 161^{\circ} 29^{\prime} \mathrm{E}$ & Dec 2004 \\
\hline Lower Wright (LWG) & McMurdo Dry Valleys, Antarctica & $77^{\circ} 23^{\prime} \mathrm{S}, 162^{\circ} 56^{\prime} \mathrm{E}$ & Nov/Dec 2004 \\
\hline John Evans (JEG) & Ellesmere Island, Canada & $79^{\circ} 49^{\prime} \mathrm{N}, 74^{\circ} 00^{\prime} \mathrm{W}$ & May 1999, May 2003 \\
\hline Engabreen (EG) & Nordland, Norway & $66^{\circ} 35^{\prime} \mathrm{N}, 13^{\circ} 59^{\prime} \mathrm{E}$ & Nov 2004, March 2006 \\
\hline
\end{tabular}


Table 2. Sample descriptions

\begin{tabular}{|c|c|c|c|}
\hline Glacier & Sample type & $\begin{array}{c}\text { Number of } \\
\text { samples }\end{array}$ & Source \\
\hline CG & $\begin{array}{l}\text { Basal ice } \\
\text { Glacier ice } \\
\text { Surface melt }\end{array}$ & $\begin{array}{l}5 \\
3 \\
1\end{array}$ & $\begin{array}{c}\text { Along a } 170 \mathrm{~cm} \text { transect at the base of the terminal ice cliff } \\
\text { Just above the basal ice on the terminal ice cliff } \\
\text { Meltwater from a supraglacial stream }\end{array}$ \\
\hline EG & $\begin{array}{l}\text { Basal ice } \\
\text { Meltwater } \\
\text { Proglacial } \\
\text { Snow } \\
\text { Subglacial }\end{array}$ & $\begin{array}{c}22 \\
1 \\
3 \\
2 \\
3\end{array}$ & 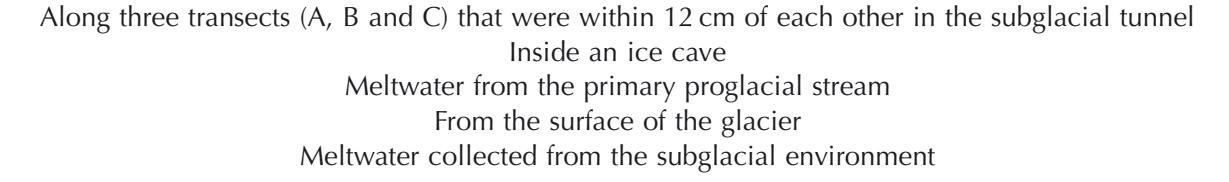 \\
\hline JEG & $\begin{array}{l}\text { Basal ice } \\
\text { Glacier ice } \\
\text { Snow }\end{array}$ & $\begin{array}{c}6 \\
13 \\
1\end{array}$ & $\begin{array}{l}\text { Along a } 200 \mathrm{~cm} \text { transect at the glacier bed on the wall of a tunnel excavated } 14 \mathrm{~m} \text { into the terminus* } \\
\text { From three ice cores (A, B and C) } 15.0,6.5 \text { and } 10.0 \mathrm{~m} \text { deep, respectively } \\
\text { From the surface of the glacier }\end{array}$ \\
\hline PoW & Snow & 6 & Surface of the ice field \\
\hline SG & $\begin{array}{l}\text { Amber glacier ice } \\
\text { Basal ice } \\
\text { Clear glacier ice } \\
\text { Glacier ice }\end{array}$ & $\begin{array}{l}1 \\
1 \\
1 \\
1\end{array}$ & $\begin{array}{c}\text { Terminal ice cliff* } \\
\text { Base of the SG terminal ice cliff }{ }^{\S} \\
\text { Bubble-free ice from the base of the terminal ice cliff } \\
\text { Terminal ice cliff }\end{array}$ \\
\hline VUG & $\begin{array}{l}\text { Glacier ice } \\
\text { Lake } \\
\text { Lake algal 'froth' } \\
\text { Proglacial } \\
\text { Surface melt }\end{array}$ & $\begin{array}{l}1 \\
1 \\
1 \\
1 \\
1\end{array}$ & $\begin{array}{c}\text { Sediment-rich layer within glacier ice exposed in the terminal ice cliff } \\
\text { Proglacial Lake Victoria } \\
\text { Algal 'froth' on the surface of proglacial Lake Victoria } \\
\text { Primary proglacial stream } \\
\text { Meltwater from a supraglacial stream }\end{array}$ \\
\hline
\end{tabular}

*Although this basal ice contained little sediment, on a plot of $\delta \mathrm{D}$ vs $\delta^{18} \mathrm{O}$ these samples lie on a slope $\left(\delta \mathrm{D}=4.8 \delta^{18} \mathrm{O}-75.5\right)$ less than that of local snow $\left(\delta \mathrm{D}=8.2 \delta^{18} \mathrm{O}+17.9\right)$ (Barker, 2007), suggesting that the basal ice formed by refreezing of meltwater rather than firnification of snow (Souchez and Jouzel, 1984).

'LWG moraine 2 contained algal mats and smelled strongly of decaying organic matter.

this sample had a slight amber tint due to its greater debris content and was not distinguished from glacier ice on the basis of its stable-isotope composition (Sleewaegen and others, 2003).

${ }^{\S}$ The sample contained debris clots that smelled strongly of dimethylsulfide.

the nearby marine system of McMurdo Sound. Aeolian transport of marine-derived OM may also be an important OM source to LWG, which, of the Dry Valley glaciers sampled, is the closest to McMurdo Sound.

JEG and PoW are located on eastern Ellesmere Island, Canada, in tundra characterized by sparse High Arctic vegetation. JEG is a polythermal glacier that has overrun OM in vegetation and soils and has incorporated OM into its basal ice (Willeslev and others, 2007). PoW is located near Nares Strait and the North Open Water polynya, and winddeposited marine-derived OM may be a locally important OM source.

EG, in the Norwegian Arctic, is located within $3 \mathrm{~km}$ of a fjord and $30 \mathrm{~km}$ of the open Atlantic Ocean, suggesting that marine aerosols may be a potentially important source of OM. Furthermore, EG is situated near a birch forest, and terrestrially derived $\mathrm{OM}$ is deposited onto the glacier surface, transported through the glacier along hydrological pathways to the subglacial environment and likely incorporated into basal ice by refreezing of subglacial water.

\section{Sampling methods and sample descriptions}

Table 2 describes the samples analyzed in this study. We collected all ice samples (except JEG ice-core samples and EG basal ice samples) using an ethanol-bathed flamesterilized chisel and aluminium collection tray. JEG ice-core samples were collected using a Kovacs ice-coring drill. EG basal ice samples were collected by inserting a precombusted $\left(450^{\circ} \mathrm{C}\right.$ for 8 hours $)$ ice screw into the basal ice exposed in the walls of an ice cave created with a hot-water drill from within the Svartisen Subglacial Laboratory. All ice samples were stored frozen in either sterile Whirlpak bags or sterile McCartney vials.

Meltwater samples were collected in acid-washed $(\mathrm{HCl})$ and pre-combusted $\left(450^{\circ} \mathrm{C}\right.$ for 8 hours) $250 \mathrm{~mL}$ amber or universal glass bottles. Each bottle was rinsed three times with filtered sample before the analytical sample was collected and frozen for storage. EG meltwater samples were filtered in the field using a manual vacuum pump and $0.7 \mu \mathrm{m}$ glass-fibre (GF/F) filter papers and were stored frozen in McCartney vials.

\section{Spectrofluorescence analysis}

The 80 samples were kept frozen from the time of collection (Table 1) until sample preparation in March-June 2008. Subsamples from the JEG ice cores were cut using a bandsaw and the ice surfaces were subsequently scraped with an ethanol-cleaned microtome blade to remove possible contamination. All samples were handled with sterile gloves and stored and melted in the dark at room temperature in sterile Whirlpak sample bags. All melted samples were filtered and stored as described above. 
Each sample was filtered through pre-combusted $\left(450^{\circ} \mathrm{C}\right.$ for 8 hours) $0.7 \mu \mathrm{m}$ glass-fibre (GF/F) filter papers using an acid-washed and pre-combusted $\left(450^{\circ} \mathrm{C}\right.$ for 8 hours $)$ glass filtration system. The upper chamber of the filtration system was rinsed three times with sample. An aliquot was then filtered to rinse the lower chamber of the system three times before the remaining volume was filtered as sample for analysis. The sample was transferred to a $40 \mathrm{~mL}$ acid-washed and pre-combusted $\left(450^{\circ} \mathrm{C}\right.$ for 8 hours) amber glass vial. Vials were stored in the dark at $\sim 4^{\circ} \mathrm{C}$ for up to 3 weeks prior to analysis, except for the EG samples which were frozen immediately after sampling and then melted and filtered directly prior to analysis. Although the effects of freeze/thaw processes on fluorescent characteristics are not well understood, large and variable responses have been observed due to freeze/thaw cycles (Spencer and others, 2007).

Replicates of a melted JEG ice-core sample were analyzed four times at 2 week intervals to determine the effect of storage on sample spectrofluorescence. Results indicate that although the peak locations did not change, the maximum fluorescent intensities of the humic- and proteinlike components differed by up to $20 \%$ between the replicates. However, the relative proportions of proteinaceous and humic DOM fluorescence remained constant; humic and proteinaceous fractions deviated $<2 \%$ between the replicate samples, whereas the standard deviation in humic:protein fluorescence ratio was $10 \%$ for the remainder of the dataset. This suggests that comparisons between total proteinaceous and humic-like DOM fluorescence remain valid. No additional replicates were taken due to the limited sample sizes available.

Filtered samples were warmed to $21^{\circ} \mathrm{C}$ in a water bath for 1-2 hours prior to analysis with a Fluorolog-3 spectrofluorometer equipped with a xenon lamp as excitation source. For analysis, samples were placed in a quartz glass cuvette, with a $10 \mathrm{~mm}$ path length, that had been rinsed three times with deionized (DI) water and three times with sample. Fluorescence scanning was performed with internal and dark correction applied. The Raman intensity of the instrument was measured using DI water at the beginning of each analysis day, with excitation set to $350 \mathrm{~nm}$, and emission intensities were measured at $2 \mathrm{~nm}$ increments from 365 to $450 \mathrm{~nm}$. The lamp intensity did not fluctuate more than $10 \%$ over the course of the analyses. EEMs were created for all samples by scanning at $2 \mathrm{~nm}$ emission wavelength increments from 300 to $550 \mathrm{~nm}$ and $5 \mathrm{~nm}$ excitation wavelength increments from 250 to $450 \mathrm{~nm}$ using an integration time of $0.5 \mathrm{~s}$ and $10 \mathrm{~nm}$ slits. DI water was also scanned each day.

\section{PARAFAC}

EEMs were Raman-corrected by subtracting the daily EEM for DI water. Data from the high-intensity area of each EEM attributable to the Rayleigh-Tyndall effect were removed (Andersen and Bro, 2003; Ohno and Bro, 2006). As fluorescent molecules always emit energy at wavelengths longer than that at which they are excited, fluorescent peaks cannot occur in areas of the spectrum in which emission wavelengths are smaller than corresponding excitation wavelengths. Data from this part of each spectrum were therefore removed (Andersen and Bro, 2003).

PARAFAC was performed in Matlab 7.6.0 using the DOMFluor toolbox (http://www.models.life.ku.dk) which contains the N-Way toolbox v.3.1 created by Andersson and Bro (2000). Code and procedures used in this study followed Stedmon and Bro (2008).

The fluorescent intensity $(\mathrm{FI})$ of a DOM component is proportional to its concentration in a sample (e.g. Parlanti and others, 2000; Christensen and others, 2005; Luciani and others, 2008; Airado-Rodríguez and others, 2009). FI varied by up to two orders of magnitude between samples. The samples with highest FI influenced the PARAFAC model dramatically as they accounted for a considerable proportion of the variance in the dataset. To minimize variation due to $\mathrm{FI}$ and to maximize the number of samples remaining in the modeled data, all EEMs were standardized to their maximum FI. This effectively reduces the inter-sample variability in $\mathrm{FI}$ and allows the analysis to focus on EEM composition. Each sample can be interpreted according to the percentage contribution of each fluorescent component to the total fluorescence of its spectrum. PARAFAC models with up to 15 components were created. Outliers with leverages $>0.5$ were removed from the dataset (Stedmon and Bro, 2008).

\section{Model validation}

Of the 15 PARAFAC models, the model with the most appropriate number of components was determined using the following criteria:

Sum of squared error: Relatively large reductions in the sum of squared error between two models favoured the model with the greater number of components, whereas relatively small reductions in the sum of squared error favoured the model with fewer components (Stedmon and Bro, 2008). In all cases, models with relatively low sum of squared error were selected.

EEM residuals: After an appropriate model has been fitted to all EEMs, only random noise should remain in the residual spectra. However, this noise may also include weakly fluorescing components that are difficult to distinguish from instrument noise, quenching effects, remnant inner filter effects and scattering effects (Stedmon and others, 2003). Residuals were inspected to ensure that the maximum possible number of discernible fluorophores was modeled correctly.

Visual inspection of the modeled components: (1) Modeled fluorescent emission peaks should have a nearGaussian distribution (Stedmon and others, 2003; Kowalczuk and others, 2005), although broad or multiple excitation peaks may exist due to electrons being excited to various vibrational sublevels (Stedmon and others, 2003). (2) Since $10 \mathrm{~nm}$ slits were used for spectrofluorescence scanning, components with peaks $<10 \mathrm{~nm}$ apart were considered not to be significantly different. (3) It was assumed that each component modeled only one group of fluorophores and that components with multiple emission peaks were poorly modeled (Stedmon and others, 2003). (4) Since data in the area of Rayleigh scatter were removed, component peaks in this region of an EEM were considered to be erroneous.

The validity of a PARAFAC model to describe variance in a dataset accurately is often evaluated using split-half analysis (Harshman and Lundy, 1984). However, split-half analysis is unlikely to validate a model if the dataset is too small relative to the intra-sample variance (Stedmon and Bro, 2008). Because the samples in this dataset are from 

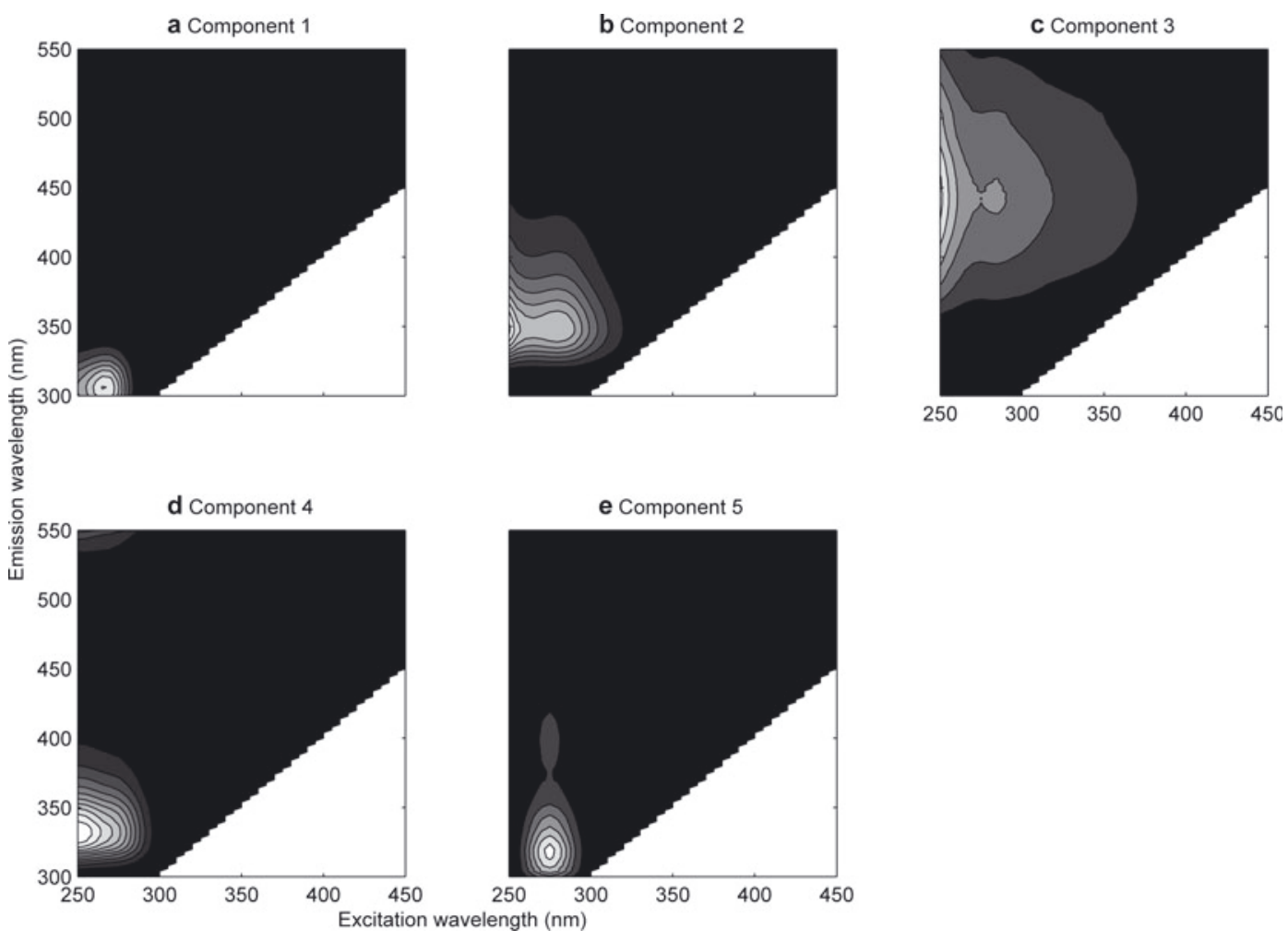

Fig. 1. EEMs for the five-component PARAFAC model.

geographically diverse locations and different sub-environments which are unlikely to be well mixed, fluorescence is expected to be highly variable. None of the models explored in this study satisfied the split-half analysis and thus it could not be used as a validation tool.

\section{Model interpretation}

The maximum relative $\mathrm{FI}(\mathrm{RFI})$ value was extracted for each component in each EEM. Although RFI values are a function of fluorophore concentration, two other factors also contribute. First, the Beer-Lambert law indicates that the intensity of light emitted upon excitation of a fluorophore is dependent on its absorption coefficient. Absorption coefficients vary with molecular characteristics and will thus differ between fluorophores. Secondly, each sample was standardized to its maximum $\mathrm{Fl}$, so component concentrations in different samples are not equally proportional to RFI. These two factors do not influence the relative contributions of each component to the overall fluorescence in an EEM. Thus, cluster analysis was performed on the relative intensities of protein-like (components 1, 2, 4 and 5) and humic-like (component 3) fluorophores in each EEM. Cluster analysis arranges a dataset into like-groups while minimizing within-group variability. The analysis was preformed in Statistica Version 8 using Euclidean distances and complete linkages. An agglomeration dendrogram plot was used to identify similarities and differences between samples, glacier systems and glacier environments.

\section{RESULTS AND DISCUSSION}

\section{Five-component PARAFAC model}

A five-component PARAFAC model (Fig. 1; Table 2) optimized the evaluation criteria outlined above and explained $98.2 \%$ of the variance in the dataset. We stress that a five-component model does not necessarily mean that the EEMs produced in this study contained only five fluorophores. The extraction of five components simply indicates that these components accounted for significant fractions of the variance in the dataset. Other fluorophores may not have been modeled because they had weak fluorescence, because their spectra were similar to those of other fluorophores or because they occurred in relatively few samples (Stedmon and others, 2003). Visual inspection of the residuals from the model EEM can be used to identify the presence of additional fluorophores. If a model describes all discernible fluorophores in an EEM correctly, only noise will remain as residual. In this study, 31 of the 69 modeled EEMs had fluorescence residual patterns containing identifiable peaks. This suggests the presence of additional fluorophore groups at wavelengths shown in Figure 2. Most of these lie in the region of 'soluble microbial by-productlike fluorophores' (Chen and others, 2003).

Although the five-component model was not validated by split-half analysis and contained residuals that suggest the presence of additional fluorophores, these represented $<1.8 \%$ of the variance in the dataset. The concern with interpreting data from an unvalidated PARAFAC model lies in the possibility that one or more of the components reflect noise rather than true fluorophore signals. This is unlikely to be the case with the five-component model presented here because it excluded recurring peaks in the residual EEMs (Fig. 2), suggesting the presence of additional fluorophores of considerably higher intensity than background noise.

\section{Component descriptions}

The fluorescent loading patterns of the five modeled components (Table 3; Fig. 1) can be matched to fluorophores described in the literature (Table 4). Component 3 has been 


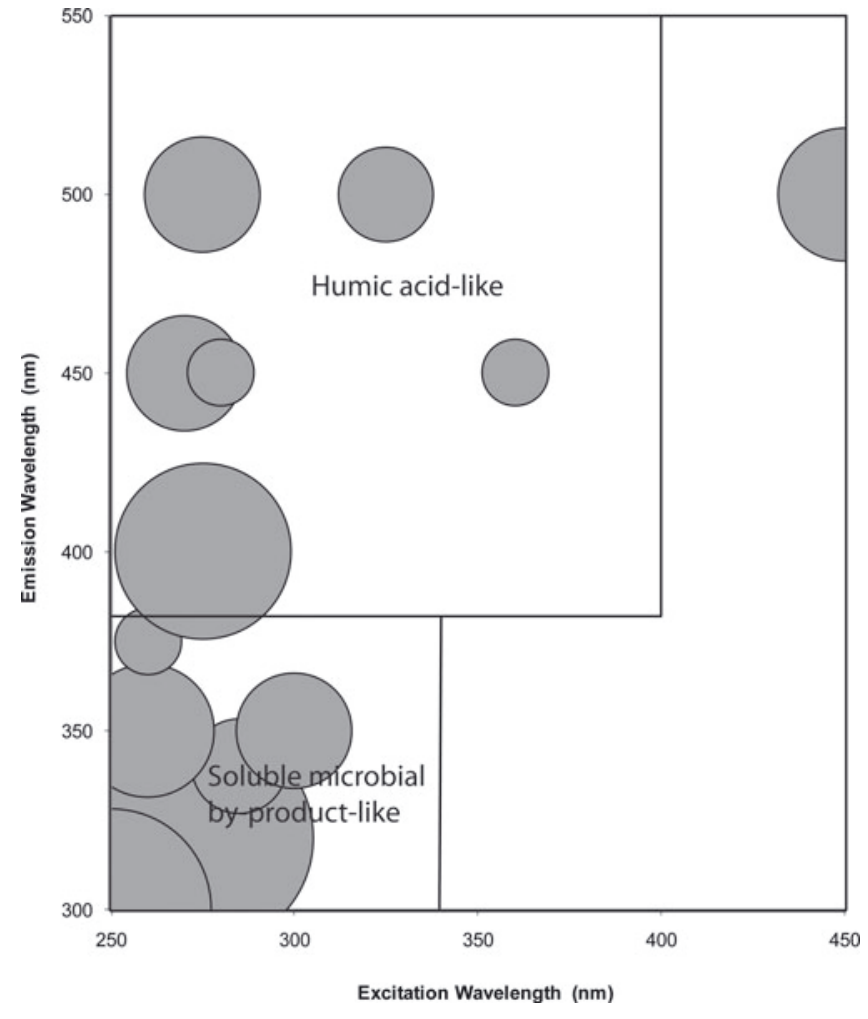

Fig. 2. Bubble plot of residual component. Bubbles are centered over visually identified residual peaks. The size of the bubbles represents the frequency at which the particular peak was observed to occur in the residuals. The peak represented by the smallest bubble has a frequency of 1 , while the peak represented by the largest bubble has a frequency of 11 . Regions of humic acid-like and soluble microbial by-product-like (Chen and others, 2003) are included.

identified previously as humic-like, while the others have been identified as protein-like.

Component 3 is similar to a humic-like peak $A$ fluorophore (Coble, 1996) described from marine and terrestrial environments (Coble and others, 1990, 1998; De Souza Sierra and others, 1994; Coble, 1996), including forests and wetlands (Stedmon and others, 2003). The relatively long emission wavelengths of this peak suggest more conjugated fluorescent molecules than are found in the other components (Sharma and Schulman, 1999). This component may therefore represent terrestrially derived humic matter of high molecular weight (Stedmon and others, 2003) that is less labile than proteinaceous OM.

Component 1 closely resembles the tryrosine-like peak B fluorophore (Coble, 1996) and indicates autochthonous production of DOM (Stedmon and Markager, 2005b). Component 2 matches the tryptophan-like fluorescent characteristics described by Lakowicz (1999) and peak T described by Coble (1996). Typically, tryptophan is associated with the autochthonous production of DOM through biological degradation (Mopper and Schultz, 1993; Coble and others, 1998; Stedmon and Markager, 2005b; Murphy and others, 2008) and its production has been observed during algal blooms (Stedmon and Markager, 2005a).

The fluorescent characteristics of component 4 cannot be interpreted directly on the basis of previous studies. The emission maximum at $330 \mathrm{~nm}$ lies between those of tryptophan-like and tyrosine-like fluorescence. The excitation maximum at $250 \mathrm{~nm}$ is at a shorter wavelength than those reported for tyrosine and tryptophan fluorescence by some authors (e.g. Coble, 1996; Stedmon and others, 2003; Stedmon and Markager, 2005a; Yamashita and others, 2008), but at a longer wavelength than reported by other authors (e.g. Marhaba and Lipincott, 2000; Marhaba and others, 2000; Parlanti and others, 2000). The emission maximum lies between those of tyrosine and tryptophan. This may be a consequence of a shifted peak, which could be attributable to: (1) formation in a different microenvironment resulting in difference in amino acid composition (Determann and others, 1998); (2) differences in concentration that influence inner filtering effects and excitation/ emission wavelengths (e.g. Mobed and others, 1996; Hautala and others, 2000); or (3) different solution properties such as pH and salinity (Stedmon and others, 2003). Several other studies have also reported red or blue shifted protein peaks (e.g. Maie and others, 2007; Yamashita and others, 2008).

The primary peak in component 5 is located between peaks T and B of Coble (1996). As both tryptophan and tyrosine are associated with amino acids in proteins, this component can be interpreted more broadly as protein-like. Component 5 has a secondary emission peak at $400 \mathrm{~nm}$ that is similar to the humic-like fluorescence of peaks A and C (Coble, 1996). As the intensity of this peak is considerably smaller than the protein-like peak, component 5 is considered to be primarily protein-like.

\section{Microbial source of DOM in glacier systems}

The four protein-like components accounted for $89 \%$ of the modeled fluorescence while the humic-like component (3) accounted for the remaining $11 \%$. Over $70 \%$ of the total modeled fluorescence in all samples is proteinaceous. This does not mean, for example, that $89 \%$ of the DOM in the dataset is proteinaceous, since each fluorophore group emits energy at different intensities according to the Beer-Lambert

Table 3. Description of the five-component PARAFAC model. Wavelengths in parentheses represent a secondary peak

\begin{tabular}{lccc}
\hline Component number & Excitation maxima & Emission maxima & Description \\
& $n$ nm & 306 & Protein-like (tyrosine-like), peak B \\
1 & 265 & 348 & Protein-like (tryptophan-like), peak T \\
2 & $<250(280)$ & 446 & Humic-like, peak A \\
3 & $<250$ & 330 & Protein-like (tyrosine-like or tryptophan-like), peak B or T \\
4 & 250 & 320 & Protein-like (tyrosine-like or tryptophan-like), peak B or T \\
5 & 275 & $(400)$ & Humic-like, peak A or C
\end{tabular}


Table 4. Relevant common fluorophores identified in previous studies

\begin{tabular}{|c|c|c|c|}
\hline $\begin{array}{l}\text { Fluorophore peak label } \\
\qquad \text { (Coble, 1996) }\end{array}$ & Fluorophore type & $\begin{array}{l}\text { Excitation maxima } \\
\qquad \mathrm{nm}\end{array}$ & $\begin{array}{l}\text { Emission maxima } \\
\mathrm{nm}\end{array}$ \\
\hline A & Humic-like & $237-260$ & $380-500$ \\
\hline $\mathrm{C}$ & Humic-like & $300-370$ & $400-500$ \\
\hline B & Protein-like (tyrosine-like) & $\begin{array}{c}225-237 \\
275\end{array}$ & $\begin{array}{c}309-321 \\
310\end{array}$ \\
\hline $\mathrm{T}$ & Protein-like (tryptophan-like) & $\begin{array}{c}220 \text { and } 280 \\
225-237 \\
275\end{array}$ & $\begin{array}{c}320-370 \\
340-381 \\
340\end{array}$ \\
\hline
\end{tabular}

Source: Coble (1996, 2007); Coble and others (1998); Lakowicz (1999); Marhaba and Lippincott (2000); Marhaba and others (2000); Parlanti and others (2000).

law. However, the proteinaceous nature of four of the five modeled components and its potentially microbial origin (e.g. Mopper and Schultz, 1993; Coble and others, 1998; Stedmon and Markager, 2005a,b) suggests a significant microbial source of DOM in these cold environments. Likewise, Barker and others (2006) concluded that DOM in glacier ice is predominantly 'microbial' in character and Lafrenière and Sharp (2004) found that DOM in glacier runoff was more 'microbial' than the more 'terrestrial' DOM in nearby snowmelt-fed streams. From a study of 11 Alaskan watersheds, Hood and others (2009) found that watersheds with high glacier cover have a higher proportion of proteinlike fluorescence than those with little or no glacier cover. This contrasts with DOM from marine, estuarine and fluvial environments, in which humic-like fluorescence makes up a more significant fraction (at least half) of the total modeled fluorescence and the predominant component(s) are humiclike (e.g. Coble, 1996; Stedmon and others, 2003; Holbrook and others, 2006; Yamashita and others, 2008).

Transformations of OM are expected to occur throughout the glacial system as environmental conditions (e.g. solar radiation, temperature, and oxygen and water availability) change. For example, in the supraglacial environment, where liquid water, solar radiation and temperatures above $0^{\circ} \mathrm{C}$ can be present, photoautotrophic microbial processes can occur (Stibal and others, 2008). Conversely, the englacial environment is characterized by cold temperatures, little to no light and limited water availability. Although viable microorganisms with different physiological characteristics have been identified englacially, it is still unknown whether they are active in situ. OM can be transformed in subglacial environments where liquid water often exists. Owing to the complete darkness and anaerobic conditions at glacier beds, these processes can involve heterotrophic and autotrophic pathways (Skidmore and others, 2000). Proglacially, where solar radiation, warm air temperatures and water are more abundant, heterotrophic, autotrophic, abiotic humification and photolysis may transform DOM more readily.

Samples did not cluster according to either the glacier system or the geographical region from which they originated, suggesting that there are no significant differences in DOM characteristics between the seven glacier systems studied (Fig. 3). For example, cluster 1 contains samples from all the glacier systems included in this study and from snow, glacier ice and basal ice. The similarities in the properties of DOM from different glaciers and glacial sub-environments and the generally proteinaceous character of DOM suggest the ubiquitous occurrence of a few relatively unique DOM fractions. This may indicate the potentially widespread presence of microbially derived DOM in glaciers. Previous work has shown the subglacial environment to be a viable microbial habitat containing diverse microbial assemblages (Sharp and others, 1999; Skidmore and others, 2000; Bhatia and others, 2006; Lanoil and others, 2009) that appear to be active (Wadham and others, 2004; Skidmore and others, 2005). Microbes have also been identified in englacial environments (Priscu and others, 1999), and surficial glacier ice and snow contain active and diverse assemblages of bacteria, cyanobacteria and algae (Stibal and others, 2006; Foreman and others, 2007; Anesio and others, 2009). Bacteria have also been identified as important snow nucleators (Carpenter and others, 2000). A number of heterotrophic and autotrophic processes may occur within the glacial system, such as methanogenesis, sulphate reduction, nitrate reduction, aerobic chemoheterotrophy (Skidmore and others, 2000) and photosynthesis (Stibal and others, 2006).

\section{Environmental occurrences of protein-like and humic-like fluorescence}

The dendrogram generated by cluster analysis performed on the RFIs for the humic- and protein-like components of each sample identified four main sample clusters defined at a linkage distance of 3 (Fig. 3). These clusters reflect differences in the relative proportions of protein- and humic-like fluorescence (Fig. 4). Clusters 1 and 2 contain samples with greater protein-like fluorescence (mean: $92.9 \pm 2.8 \%$ ), whereas clusters 3 and 4 contain samples with relatively more humic-like fluorescence (mean: $19.1 \pm 4.6 \%$; Fig. 4).

Samples from all glacier systems (except CG) are found in all clusters. CG samples have consistently high protein-like fluorescence and are found only in clusters 1 and 2. Samples of snow and glacier ice are found throughout the dendrogram and have similar DOM characteristics, likely because glacier ice is formed from snow. This suggests that both snow and glacier ice acquire OM from atmospheric sources (e.g. snow-nucleating bacteria, wind-blown material) or from microbial production on the glacier surface.

Basal ice samples are also found in all clusters. Basal ice forms by the accretion of ice and debris onto the base of the glacier through processes of regelation and congelation (Knight, 1997). Regelation involves the refreezing of water 


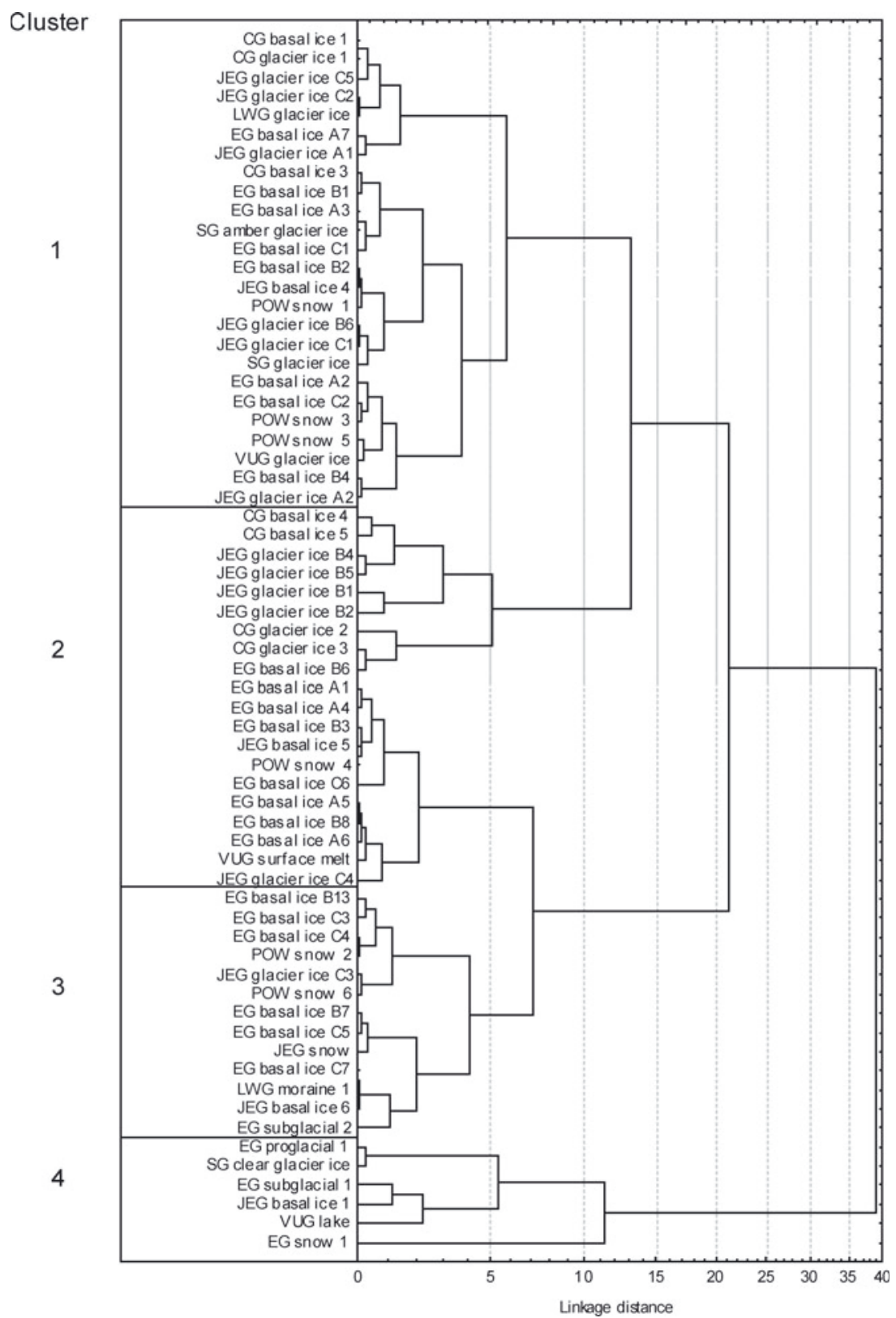

Fig. 3. Cluster analysis using the total protein-like and humic-like RFIs for the modeled EEMs. Euclidean distances and complete linkages were applied.

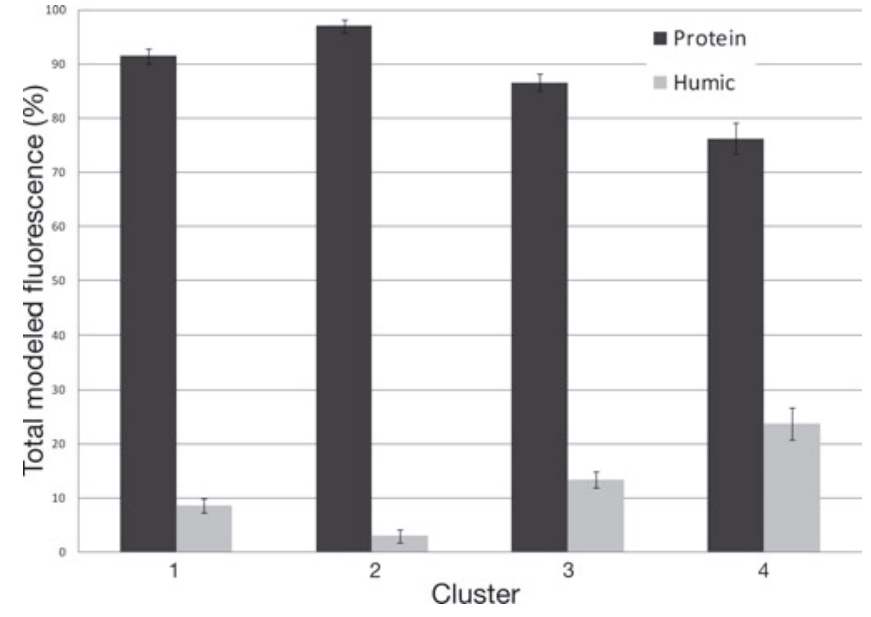

Fig. 4. Average percent of total modeled fluorescence for each cluster. Error bars indicate one standard deviation. that originates from localized pressure-induced melting at the glacier bed, while congelation involves the formation of ice at the base of the glacier from water derived primarily from melting at the glacier surface. Although it is possible that basal ice has acquired much of its OM through the recycling of glacier ice, these sub-environments contain very different microbial habitats, chemical environments and OM sources (e.g. Skidmore and others, 2000; Bhatia and others, 2006). The spectrofluorescence analysis has not captured these differences. However, four basal ice samples, from JEG, CG and SG, were identified as outliers from the model and were removed from the dataset (Fig. 5b-e). The unique spectra of these samples were not effectively described by the five-component PARAFAC model, suggesting the presence of unique DOM in the subglacial environment at these glaciers.

The modeled meltwater samples are clustered alongside samples from other subglacial, englacial and supraglacial environments (Figs 3 and 4), suggesting that glacier 


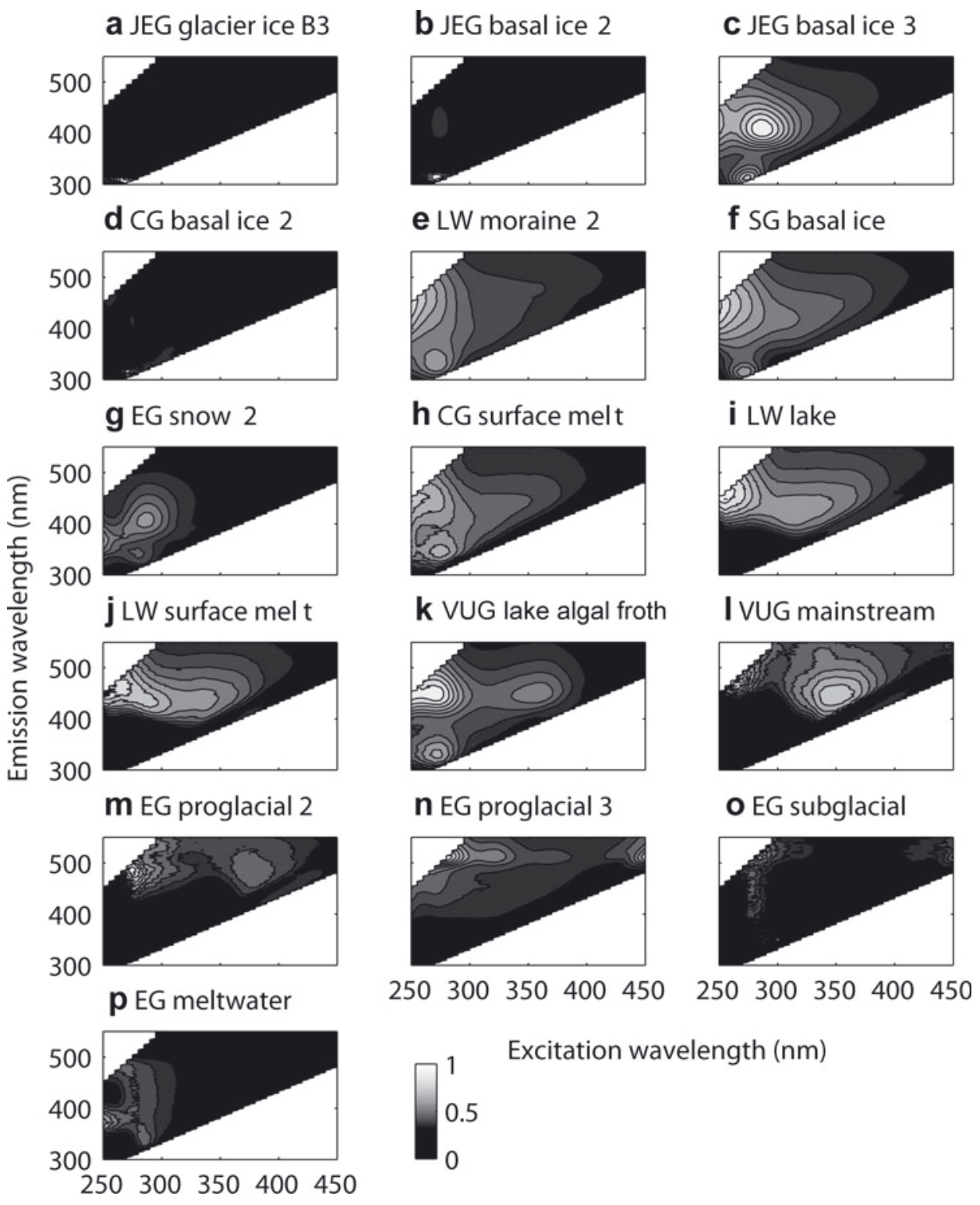

Fig. 5. Unmodeled EEMs for the 16 outliers removed during PARAFAC modeling. (a-g) Ice samples; (h-p) water samples.

meltwater either inherits DOM characteristics from its source ice and/or has similar OM sources. For example, the three meltwater samples from EG are similar to the majority of basal ice samples from EG and contain a relatively high proportion of humic-like fluorescence (Figs 3 and 4). This confirms the routing of runoff at EG through the subglacial environment (Lappegard and others, 2006). This is especially true of the winter months when the sampling was conducted. At this time, subglacial meltwater is the primary water source to the proglacial stream since there is almost no surface melting. The OM source in this case is likely to be glacially overridden or inwashed soils from the local birch forest.

Although meltwater samples are broadly similar to glacier ice samples, they are significantly over-represented in clusters 3 and 4, while glacier ice samples are significantly over-represented in clusters 1 and $2\left(\chi^{2}=14.2, \mathrm{df}=7\right.$, $p<0.05$ ) (Fig. 3). Clusters 3 and 4 have notably higher humic-like:protein-like fluorescence ratios than clusters 1 and 2 (Fig. 4). Furthermore, 9 of the 16 samples removed as outliers with leverages $>0.5$ during PARAFAC runs were proglacial and supraglacial water samples from CG, LWG,
VUG and EG (Fig. 5h-p). These samples also contained primarily humic-like fluorophores (Figs 2 and 5h-p). Possible explanations for the high humic-like:protein-like fluorescence ratios in meltwater samples include the following: (1) meltwater may access humic OM sources as it is routed through the glacier and proglacial environment; (2) labile proteinaceous DOM may be removed from samples by microbial consumption of tryptophan or tyrosine (Parlanti and others, 2000), by abiotic humification or by photolysis of DOM into non-fluorescent forms (Bertilsson and Jones, 2003), which may not occur to the same extent in ice and snow; and (3) aquatic environments may be more favourable than ice environments for the production of humic-like fluorophores, especially if waters have access to supplies of terrestrial nutrients.

\section{CONCLUSIONS}

PARAFAC was performed on spectrofluorescence data from the subglacial, englacial, supraglacial and proglacial environments of seven glacier systems in the McMurdo 
Dry Valleys, Antarctica; Ellesmere Island, Canada; and the Norwegian Arctic. DOM from the different glacier systems can be described by five fluorescent components: one humic-like and four protein-like (one tyrosine-like, one tryptophan-like and two undefined).

In contrast to DOM from marine, estuarine and fluvial environments, which is dominated by humic-like material, DOM from glacier systems is dominated by protein-like DOM that may be derived microbially. Other studies have reported similar protein-like DOM from glacial runoff in Alaska (Hood and others, 2009), Canada (Lafrenière and Sharp, 2004; Barker and others, 2006, 2009) and in ice from an Antarctic glacier (Barker and others, 2006). There were no significant differences in the fluorophores present in DOM from the range of glacier systems studied here, despite differences in geographic location, glacier thermal regime and potential OM sources. Although DOM from ice (basal, englacial and surficial), snow and meltwater samples has remarkably similar characteristics, meltwater samples do have consistently higher humic-like:protein-like fluorescence ratios than snow and ice samples. This suggests that either additional humic DOM is introduced to the meltwater as it is routed through the glacier system or protein-like DOM is removed from meltwater by organic processes, such as heterotrophy (e.g. Fellman and others, 2008), or through inorganic process such as abiotic humification (e.g. Parlanti and others, 2000) occurring along the flow route or photolysis (e.g. Miller and others, 2009).

\section{ACKNOWLEDGEMENTS}

This research was funded by the Natural Sciences and Engineering Research Council of Canada (Discovery and Research Tools and Instruments grants, Undergraduate Summer Research Assistantship), the Canada Foundation for Innovation, Polar Continental Shelf Project, Canadian Circumpolar Institute, Northern Scientific Training Program, Antarctica New Zealand, Environment Canada and the UK Natural Environment Research Council. We thank the Nunavut Research Institute and the communities of Grise Fjord and Resolute Bay for permission to conduct research on Ellesmere Island, the Norwegian Water Resources and Energy Directorate for allowing access to the Svartisen Subglacial Laboratory, and the anonymous reviewers of this paper.

\section{REFERENCES}

Airado-Rodríguez, D., T. Galeano-Díaz, I. Durán-Merás and J.P. Wold. 2009. Usefulness of fluorescence excitation-emission matrices in combination with PARAFAC, as fingerprints of red wines. J. Agric. Food Chem., 57(5), 1711-1720.

Andersen, C.M. and R. Bro. 2003. Practical aspects of PARAFAC modeling of fluorescence excitation-emission data. J. Chemometr., 17(4), 200-215.

Andersson, C.A. and R. Bro. 2000. The N-way Toolbox for MATLAB. Chem. Intell. Lab. Syst., 52(1), 1-4.

Anesio, A.M., A.J. Hodson, A. Fritz, R. Psenner and B. Sattler. 2009. High microbial activity on glaciers: importance to the global carbon cycle. Global Change Biol., 15(4), 955-960.

Banaitis, M.R. and 6 others. 2006. Investigating sorption-driven dissolved organic matter fractionation by multidimensional fluorescence spectroscopy and PARAFAC. J. Colloid Interface Sci., 304(1), 271-276.
Barker, J.D. 2007. An investigation of the abundance and molecular characteristics of organic matter in glacier systems. (PhD thesis, University of Alberta.)

Barker, J.D., M.J. Sharp, S.J. Fitzsimons and R.J. Turner. 2006. Abundance and dynamics of dissolved organic carbon in glacier systems. Arct. Antarct. Alp. Res., 38(2), 163-172.

Barker, J.D., M.J. Sharp and R.J. Turner. 2009. Using synchronous fluorescence spectroscopy and principal components analysis to monitor dissolved organic matter dynamics in a glacier system. Hydrol. Process., 23(10), 1487-1500.

Bertilsson, S. and J.B. Jones. 2003. Supply of dissolved organic matter to aquatic ecosystems: autochthonous sources. In Findlay, S.E.G. and R.L. Sinsabaugh, eds. Aquatic ecosystems: interactivity of dissolved organic matter (aquatic ecology). San Diego, CA, Academic Press, 3-24

Bhatia, M., M. Sharp and J. Foght. 2006. Distinct bacterial communities exist beneath a High Arctic polythermal glacier. Appl. Environ. Microbiol., 72(9), 5838-5845.

Bhatia, M.P., S.B. Das, K. Longnecker, M.A. Charette and E.B. Kujawinski. 2010. Molecular characterization of dissolved organic matter associated with the Greenland ice sheet. Geochim. Cosmochim. Acta, 74(13), 3768-3784.

Bro, R. 1997. PARAFAC. Tutorial and applications. Chem. Intell. Lab. Syst., 38(2), 149-171.

Bro, R. 1999. Exploratory study of sugar production using fluorescence spectroscopy and multi-way analysis. Chem. Intell. Lab. Syst., 46(2), 133-147.

Carpenter, E.J., S. Lin and D.G. Capone. 2000. Bacterial activity in South Pole snow. Appl. Environ. Microbiol., 66(10), 4514-4517.

Chen, W., P. Westerhoff, J.A. Leenheer and K. Booksh. 2003. Fluorescence excitation-emission matrix regional integration to quantify spectra for dissolved organic matter. Environ. Sci. Technol., 37(24), 5701-5710.

Christensen, J., E. Miquel Becker and C.S. Frederiksen. 2005. Fluorescence spectroscopy and PARAFAC in the analysis of yogurt. Chem. Intell. Lab. Syst., 75(2), 201-208.

Coble, P.G. 1996. Characterization of marine and terrestrial DOM in seawater using excitation-emission matrix spectroscopy. Mar. Chem., 51(4), 325-346.

Coble, P.G. 2007. Marine optical biogeochemistry: the chemistry of ocean color. Chem. Rev., 107(2), 402-418.

Coble, P.G., S.A. Green, N.V. Blough and R.B. Gagosian. 1990. Characterization of dissolved organic matter in the Black Sea by fluorescence spectroscopy. Nature, 348(6300), 432-435.

Coble, P.G., C.E. del Castillo and B. Avril. 1998. Distribution and optical properties of CDOM in the Arabian Sea during the 1995 Southwest Monsoon. Deep-Sea Res. II, 45(10-11), 2195-2223.

De Souza Sierra, M.M., O.F.X. Donard, M. Lamotte, C. Belin and M. Ewald. 1994. Fluorescence spectroscopy of coastal and marine waters. Mar. Chem., 47(2), 127-144.

Determann, S., J.M. Lobbes, R. Reuter and J. Rullkötter. 1998. Ultraviolet fluorescence excitation and emission spectroscopy of marine algae and bacteria. Mar. Chem., 62(1-2), 137-156.

Fellman, J.B., D.V. D'Amore, E. Hood and R.D. Boone. 2008. Fluorescence characteristics and biodegradability of dissolved organic matter in forest and wetland soils from coastal temperate watersheds in southeast Alaska. Biogeochem., 88(2), 169-184.

Findlay, S.E.G. and R.L. Sinsabaugh. 2003. Aquatic ecosystems: interactivity of dissolved organic matter. San Diego, CA, Academic Press.

Foght, J. and 6 others. 2004. Culturable bacteria in subglacial sediments and ice from two Southern Hemisphere glaciers. Microbial Ecol., 47(4), 329-340.

Foreman, C.M., B. Sattler, D.L. Mikucki, D.L. Porazinska and J.C. Priscu. 2007. Metabolic activity and diversity of cryoconites in the Taylor Valley, Antarctica. J. Geophys. Res., 112(G4), G04S32. (10.1029/2006JG000358.) 
Hall, B.L., G.H. Denton and B. Overturf. 2001. Glacial Lake Wright, a high-level Antarctic lake during the LGM and early Holocene. Antarct. Sci., 13(1), 53-60.

Harshman, R.A. and M.E. Lundy. 1984. The PARAFAC model for three-way factor analysis and multidimensional scaling. In Law, H.G., C.W. Snyder, Jr, J.A. Hattie and R.P. McDonald, eds. Research methods for multimode data analysis. New York, Praeger, 122-215.

Hautala, K., J. Peuravuori and K. Pihlaja. 2000. Measurement of aquatic humus content by spectroscopic analyses. Water Res. 34(1), 246-258.

Holbrook, R.D., J.H. Yen and T.J. Grizzard. 2006. Characterizing natural organic material from the Occoquan Watershed (Northern Virginia, US) using fluorescence spectroscopy and PARAFAC. Sci. Total Environ., 361(1-3), 249-266.

Hood, E. and 6 others. 2009. Glaciers as a source of ancient and labile organic matter to the marine environment. Nature, 462(7276), 1044-1047.

Hudson, N., A. Baker and D. Reynolds. 2007. Fluorescence analysis of dissolved organic matter in natural, waste and polluted waters - a review. River Res. Appl., 23(6), 631-649.

Knight, P.G. 1997. The basal ice layer of glaciers and ice sheets. Quat. Sci. Rev., 16(9), 975-993.

Kowalczuk, P., J. Stoé-Egiert, W.J. Cooper, R.F. Whitehead and M.J. Durako. 2005. Characterization of chromophoric dissolved organic matter (CDOM) in the Baltic Sea by excitation emission matrix fluorescence spectroscopy. Mar. Chem., 96(3-4), 273-292.

Lafrenière, M.J. and M.J. Sharp. 2004. The concentration and fluorescence of dissolved organic carbon (DOC) in glacial and nonglacial catchments: interpreting hydrological flow routing and DOC sources. Arct. Antarct. Alp. Res., 36(2), 156-165.

Lakowicz, J.R. 1999. Principles of fluorescence spectroscopy. Second edition. New York, Springer.

Lanoil, B. and 7 others. 2009. Bacteria beneath the West Antarctic Ice Sheet. Environ. Microbiol., 11(3), 609-615.

Lappegard, G., J. Kohler, M. Jackson and J.O. Hagen. 2006. Characteristics of subglacial drainage systems deduced from load-cell measurements. J. Glaciol., 52(176), 137-148.

Leenheer, J.A. and J.-P. Croué. 2003. Characterizing aquatic dissolved organic matter. Environ. Sci. Technol., 37(1), 18A-26A

Luciani, X. and 8 others. 2008. Tracing of dissolved organic matter from the SEPETIBA Bay (Brazil) by PARAFAC analysis of total luminescence matrices. Mar. Environ. Res., 65(2), $148-157$

Maie, N., N.M. Scully, O. Pisani and R. Jaffé. 2007. Composition of a protein-like fluorophore of dissolved organic matter in coastal wetland and estuarine ecosystems. Water Res., 41(3), 563-570.

Marhaba, T.F. and R.L. Lippincott. 2000. Application of fluorescence technique for rapid identification of DOM fractions in source waters. ASCE J. Environ. Eng., 126(11), 1039-1044.

Marhaba, T.F., D. Van and R.L. Lippincott. 2000. Rapid identification of dissolved organic matter fractions in water by spectral fluorescent signatures. Water Res., 34(14), 3543-3550.

Miller, M.P., D.M. McKnight and S.C. Chapra. 2009. Production of microbially-derived fulvic acid from photolysis of quinonecontaining extracellular products of phytoplankton. Aquat. Sci., 71(2), 170-178.

Mobed, J.J., S.L. Hemmingsen, J.L. Autry and L.B. McGown. 1996. Fluorescence characterization of IHSS humic substances: total luminescence spectra with absorbance correction. Environ. Sci. Technol., 30(10), 3061-3065.

Mopper, K. and C.A. Schultz. 1993. Fluorescence as a possible tool for studying the nature and water column distribution of DOC components. Mar. Chem., 41(1-3), 229-238.

Mopper, K., Z. Feng, S.B. Bentjen and R.F. Chen. 1996. Effects of cross-flow filtration on the absorption and fluorescence properties of seawater. Mar. Chem., 55(1-2), 53-74.
Mulholland, P.J. 2003. Large-scale patterns in dissolved organic carbon concentration, flux, and sources. In Findlay, S.E.G. and R.L. Sinsabaugh, eds. Aquatic ecosystems: interactivity of dissolved organic matter. San Diego, CA, Academic Press.

Murphy, K.R., C.A. Stedmon, T.D. Waite and G.M. Ruiz. 2008. Distinguishing between terrestrial and autochthonous organic matter sources in marine environments using fluorescence spectroscopy. Mar. Chem., 108(1-2), 40-58.

Ohno, T. and R. Bro. 2006. Dissolved organic matter characterization using multiway spectral decomposition of fluorescence landscapes. Soil Sci. Soc. Am. J., 70(6), 2028-2037.

Parlanti, E., K. Wortz, L. Geoffroy and M. Lamotte. 2000. Dissolved organic matter fluorescence spectroscopy as a tool to estimate biological activity in a coastal zone submitted to anthropogenic inputs. Org. Geochem., 31(12), 1765-1781.

Price, P.B. 2000. A habitat for psychrophiles in deep Antarctic ice. Proc. Natl Acad. Sci. USA (PNAS), 97(3), 1247-1251.

Priscu, J.C. and 11 others. 1999. Geomicrobiology of subglacial ice above Lake Vostok, Antarctica. Science, 286(5447), 2141-2144.

Priscu, J.C., B.C. Christner, C.M. Foreman and G. Royston-Bishop. 2006. Biological material in ice cores. In Elias, S.A., ed. Encyclopedia of Quaternary Sciences, Vol. 2. Amsterdam, Elsevier, 1156-1166.

Rutledge, D.N. and D.J.R. Bouveresse. 2007. Multi-way analysis of outer product arrays using PARAFAC. Chem. Intell. Lab. Syst., 85(2), 170-178.

Sharma, A. and S.G. Schulman. 1999. Introduction to fluorescence spectroscopy. New York, Wiley.

Sharp, M., J. Parkes, B. Cragg, I.J. Fairchild, H. Lamb and M. Tranter. 1999. Widespread bacterial populations at glacier beds and their relationship to rock weathering and carbon cycling. Geology, 27(2), 107-110.

Skidmore, M.L., J.M. Foght and M.J. Sharp. 2000. Microbial life beneath a high Arctic glacier. Appl. Environ. Microbiol., 66(8), 3214-3220.

Skidmore, M., S.P. Anderson, M. Sharp, J. Foght and B.D. Lanoil. 2005. Comparison of microbial community compositions of two subglacial environments reveals a possible role for microbes in chemical weathering processes. Appl. Environ. Microbiol., 71(11), 6986-6997.

Sleewaegen, S., D. Samyn, S.J. Fitzsimons and R.D. Lorrain. 2003. Equifinality of basal ice facies from an Antarctic cold-based glacier. Ann. Glaciol., 37, 257-262.

Sleighter, R.L. and P.G. Hatcher. 2008. Molecular characterization of dissolved organic matter (DOM) along a river to ocean transect of the lower Chesapeake Bay by ultrahigh resolution electrospray ionization Fourier transform ion cyclotron resonance mass spectrometry. Mar. Chem., 110(3-4), 140-152.

Smilde, A., R. Bro and P. Geladi. 2004. Multi-way analysis: applications in the chemical sciences. Chichester, Wiley.

Souchez, R.A. and J. Jouzel. 1984. On the isotopic composition in $\delta \mathrm{D}$ and $\delta^{18} \mathrm{O}$ of water and ice during freezing. J. Glaciol., 30(106), 369-372.

Spencer, R.G.M., L. Bolton and A. Baker. 2007. Freeze/thaw and $\mathrm{pH}$ effects on freshwater dissolved organic matter fluorescence and absorbance properties from a number of UK locations. Water Res., 41(13), 2941-2950.

Stedmon, C.A. and R. Bro. 2008. Characterizing dissolved organic matter fluorescence with parallel factor analysis: a tutorial. Limnol. Oceanogr. Meth., 6, 572-579.

Stedmon, C.A. and S. Markager. 2005a. Resolving the variability of dissolved organic matter fluorescence in a temperate estuary and its catchment using PARAFAC analysis. Limnol. Oceanogr., 50(2), 686-697.

Stedmon, C.A. and S. Markager. 2005b. Tracing the production and degradation of autochthonous fractions of dissolved organic matter using fluorescence analysis. Limnol. Oceanogr., 50(5), $1415-1426$. 
Stedmon, C.A., S. Markager and R. Bro. 2003. Tracing dissolved organic matter in aquatic environments using a new approach to fluorescence spectroscopy. Mar. Chem., 82(3-4), 239-254.

Stibal, M., M. Šabacká and K. Kaštovská. 2006. Microbial communities on glacier surfaces in Svalbard: impact of physical and chemical properties on abundance and structure of cyanobacteria and algae. Microbial Ecol., 52(4), 644-654.

Stibal, M., M. Tranter, L.G. Benning and J. Rehák. 2008. Microbial primary production on an Arctic glacier is insignificant in comparison with allochthonous organic carbon input. Environ. Microbiol., 10(8), 2172-2178.

Wadham, J.L., S. Bottrell, M. Tranter and R. Raiswell. 2004. Stable isotope evidence for microbial sulphate reduction at the bed of a polythermal high Arctic glacier. Earth Planet. Sci. Lett., 219(3-4), 341-355.

Wadham, J.L., M. Tranter, S. Tulaczyk and M. Sharp. 2008. Subglacial methanogenesis: a potential climatic amplifier? Global Biogeochem. Cycles, 22(2), GB2021. (10.1029/ 2007GB002951.)

Willerslev, E. and 29 others. 2007. Ancient biomolecules from deep ice cores reveal a forested southern Greenland. Science, 317(5834), 111-114.

Yamashita, Y., R. Jaffé, N. Maie and E. Tanoue. 2008. Assessing the dynamics of dissolved organic matter (DOM) in coastal environments by excitation emission matrix fluorescence and parallel factor analysis (EEM-PARAFAC). Limnol. Oceanogr., 53(5), 1900-1908. 